\title{
Strategi Polres Madiun dalam manajemen konflik pencak silat
}

\section{Strategy implemented by the Madiun Police Department in conflict management of pencak silat}

\author{
I Made Jata Wiranegara ${ }^{凶}$ \\ Polresta Madiun \\ Madiun, 63471, Jawa Timur, Indonesia
}

E-mail corresponding author: i.made.jata.wiranegara-2016@pasca.unair.ac.id

\begin{abstract}
Abstrak
Manajemen konflik Pencak Silat PSHT dan PSHW di Kabupaten Madiun mengalami kendala internal. Penelitian ini bertujuan untuk mengetahui dan menganalisis strategi Polisi Daerah Madiun dalam pengelolaan konflik seni bela diri PSHT dan PSHW. Metode penelitian yang digunakan ialah kualitatif dan studi kasus. Teknik pengumpulan data yang digunakan adalah wawancara, observasi, dan dokumentasi. Hasil penelitian menunjukkan bahwa konflik seni bela diri PSHT dan PSHW pada dasarnya disebabkan oleh beberapa faktor, seperti faktor perbedaan sejarah, perbedaan manajemen, dan faktor pengiriman pengajaran yang berbeda. Kemudian konflik PSHT dan PSHW terjadi pada saat-saat tertentu, seperti di Nyekar 1 Muharam oleh PSHT dan Suran Agung oleh PSHW. Pola kejahatan akibat konflik antara PSHT dan PSHW, yaitu ancaman dengan senjata, penganiayaan, dan penghancuran. Ada tiga tahap untuk mengelola konflik di Madiun terkait dengan konflik seni bela diri PSHW dan PSHT, yaitu pre-emptive, preventive, dan repressive.
\end{abstract}

Kata kunci: strategi; konflik; pencak silat; manajemen; kepolisian

\begin{abstract}
The management of conflict between Pencak Silat groups of PSHT and PSHW in Madiun is experiencing internal constraints. The research aims to identify and analyze the strategy of Madiun Police Department in the management of this conflict. The research was designed as qualitative case studies. Data were collected from interviews, observations, and documentation. Results show that PSHT and PSHW conflict is essentially due to several factors: historical differences, managerial differences, and differences in teaching delivery. The study also finds that this conflict occurs during particular times: Nyekar 1 Muharam for PSHT and Suran Agung for PSHW. Three types of crime commonly accompany the conflict: threats with weapons, persecution, and destruction of properties. Three stages of conflict management implemented by the regional police department are identified in this particular case of disputes between the two martial arts groups: pre-emptive, preventive, and repressive.
\end{abstract}

Keywords: strategy; conflict; pencak silat; management; police

\section{Pendahuluan}

Di daerah Madiun dan sekitarnya terdapat banyak organisasi beladiri atau perguruan silat yang lahir dan berpusat di Kota Madiun. Pencak Silat sebagai warisan budaya dan cabang olah raga beladiri telah menarik minat warga masyarakat terutama para remaja di daerah Madiun dan sekitarnya untuk terlibat di dalamnya (Indriatmiko 2016). Beberapa organisasi beladiri atau perguruan pencak silat di Kota Madiun, antara lain: Persaudaraan Setia Hati Terate (PSHT), Persaudaraan Setia Hati Winongo (PSHW), Kera Sakti, Tapak Suci, Pagar Nusa, Cempaka Putih, Pro Patria dan lain-lain.

Organisasi beladiri tersebut sebagian telah meningkat jumlah pengikutnya dan menciptakan fanatik kelompok yang berlebihan (Mohamad 2018). Sayangnya, organisasi yang telah diakui oleh Pemerintah Daerah melalui Peraturan Walikota tersebut, justru banyak menimbulkan keresahan sosial akibat konflik yang berkepanjangan (Prastya 2016). Fanatisme telah menciptakan sekat pembatas dalam kehidupan bermasyarakat yang mengakibatkan rawan korban jiwa dan harta (Colas 1997; Laqueur 2000). Hal ini disebabkan oleh anggota muda perguruan persaudaraan pencak silat yang masih labil dan saling unjuk kekuatan serta saling mengejek. Jiwa muda yang fanatik rentan terbakar masalah pribadi, kelompok dan politik (Olson 2007; Toscano 2017). Konflik yang melibatkan masa pendukung kedua pihak antara perguruan silat Setia Hati Terate dengan Setia Hati Winongo telah 
menimbulkan keresahan di berbagai lapisan masyarakat, bahkan sudah pernah mengakibatkan korban jiwa dan harta benda dari kedua belah pihak serta masyarakat pada umumnya (Maksum 2009; Rosanty 2011).

Adanya konflik dua perguruan PSHT dan PSHW yang terus berkelanjutan dapat mengakibatkan terjadinya gangguan kamtibmas diwilayah Madiun dan sekitarnya. Kepolisian Resort Madiun telah memperkuat peran dan fungsi pemolisian masyarakat sebagai imbangan dalam mengatasi dan mencegah terjadinya konflik antara PSHT dan PSHW di Madiun (Iswati et al. 2018). Data menunjukkan dari 147 kasus konflik antarperguruan yang masuk di Polres Madiun 2008 sampai 2012, ternyata hanya dapat ditangani $65 \%$ saja melalui cara-cara konvensional (kawal, jaga, tangkap). Melalui penguatan peran pemolisian masyarakat, maka saat ini kasus- kasus kekerasan yang bersifat kelompok mulai dapat ditemukan solusinya.

Pasal 1 ayat (1) Undang- Undang Republik Indonesia Nomor 7 Tahun 2012 Tentang Penanganan Konflik Sosial menentukan bahwa yang dimaksud dengan konflik sosial adalah konflik sosial yang selanjutnya disebut konflik, adalah perseteruan dan/atau benturan fisik dengan kekerasan antara dua kelompok masyarakat atau lebih yang berlangsung dalam waktu tertentu dan berdampak luas yang mengakibatkan ketidakamanan dan disintegrasi sosial sehingga mengganggu stabilitas nasional dan menghambat pembangunan nasional. Konflik sosial merupakan salah satu proses disosiatif dari interaksi sosial, di samping proses interaksi sosial lainnya, yang tergolong proses disosiatif, seperti kerja sama, akomodasi, dan yang tergolong proses disosiatif lainnya, yaitu persaingan (Coser 1967; Coser 1998). Setiap masyarakat selalu menyimpan potensi konflik, kendati kelihatannya masyarakat terlihat bersepakat, akan tetapi pada hakikatnya anggota- anggota masyarakat terbagi ke dalam kubukubu yang berlawanan walaupun tidak secara terbuka atau tersembunyi (Dahrendorf 1958; Dahrendorf 2011).

Pasal 5 Undang-Undang Republik Indonesia Nomor 7 Tahun 2012 Tentang Penanganan Konflik Sosial menentukan bahwa konflik sosial dapat terjadi karena hal-hal berikut : a) permasalahan yang berkaitan dengan politik, ekonomi, dan sosial budaya; b) perseteruan antarumat beragama dan/atau interumat beragama, antarsuku, dan antaretnis; c) sengketa batas wilayah desa, kabupaten/kota, dan/atau provinsi; d) sengketa sumber daya alam antarmasyarakat dan/atau antarmasyarakat dengan pelaku usaha; atau e) distribusi sumber daya alam yang tidak seimbang dalam masyarakat.

Pengertian penanganan konflik diatur dalam dalam Pasal 1 ayat (2) Undang-Undang Republik Indonesia Nomor 7 Tahun 2012 Tentang Penanganan Konflik Sosial, yang menyebutkan bahwa Penanganan Konflik adalah serangkaian kegiatan yang dilakukan secara sistematis dan terencana dalam situasi dan peristiwa baik sebelum, pada saat, maupun sesudah terjadi Konflik yang mencakup pencegahan konflik, penghentian konflik, dan pemulihan pascakonflik. Sedangkan pencegahan konflik sosial disebutkan dalam Pasal 1 ayat (3) Undang-Undang Republik Indonesia Nomor 7 Tahun 2012 Tentang Penanganan Konflik Sosial, yang menyebutkan bahwa "Pencegahan Konflik adalah serangkaian kegiatan yang dilakukan untuk mencegah terjadinya Konflik dengan peningkatan kapasitas kelembagaan dan sistem peringatan dini”. Pencegahan konflik sosial merupakan salah satu tindakan dari penanganan konflik sosial. Pasal 4 Undang- Undang Republik Indonesia Nomor 7 Tahun 2012 Tentang Penanganan Konflik Sosial, menentukan bahwa ruang lingkup penanganan konflik sosial meliputi pencegahan, penghentian konflik sosial serta pemulihan pasca konflik sosial. Pencegahan konflik sosial diatur dalam Pasal 6,7, 8, 9, 10, 11 Undang-Undang Republik Indonesia Nomor 7 Tahun 2012 Tentang Penanganan Konflik Sosial.

Pencak silat adalah salah satu olahraga beladiri yang berakar dari bangsa Melayu. Dari segi linguistik kawasan orang Melayu adalah kawasan Laut Teduh yang membentang dari Easter Island di sebelah timur ke pulau Madagaskar di sebelah barat (Kartomi 2011; Kumaidah 2012). Lebih terinci dengan etnis Melayu biasanya disebut penduduk yang terdampar di kepulauan yang meliputi Malaysia, Indonesia, Singapura, Brunei Darusalam, Filipina dan beberapa pulau kecil yang berdekatan dengan negara-negara tersebut. Walaupun sebetulnya penduduk Melayu adalah suatu etnis di antara ratusan etnis yang mendiami kawasan itu. Silat adalah intisari pencak untuk secara fisik membela diri dan 
tidak dapat digunakan untuk pertunjukan. Silat adalah gerak bela-serang yang erat hubungannya dengan rohani, sehingga menhidup-suburkan naluri, menggerakkan hati nurani manusia dan berserah diri kepada Tuhan Yang Maha Esa (Wilson 2002; Mardotillah \& Zein 2017). Sama halnya diungkapkan oleh Suharso juga mengatakan, Pencak adalah permainan (keahlian) untuk mempertahankan diri dengan kepandaian menangkis, mengelak dan sebagainya. Sedangkan Silat adalah kepandaian berkelahi dengan ketangkasan menyerang dengan membela diri.

\section{Metode Penelitian}

Dalam penelitian ini pendekatan yang digunakan adalah kualitatif dengan menggunakan metode studi kasus (case study), dimana dalam kajiannya mencoba menjelaskan keputusan-keputusan tentang mengapa studi tersebut dipilih, bagaimana mengimplementasikannya dan apa hasilnya. Hasil penelitiannya ditekankan pada memberikan gambaran secara objektif tentang keadaan sebenarnya dari objek yang diselidiki, yang mana berkaitan dengan strategi Polres Madiun dalam manajemen konflik Pencak Silat PSHT dan PSHW di Kabupaten Madiun.

Data primer adalah data yang dikumpulkan oleh peneliti sendiri atau dirinya sendiri. Ini adalah data yang belum pernah dikumpulkan sebelumnya, baik dengan cara tertentu atau pada periode waktu tertentu. Adapun dalam penelitian ini yang termasuk data primer yaitu Wawancara dan Observasi. Data sekunder merupakan data yang diperoleh atau dikumpulkan oleh orang yang melakukan penelitian dari sumber-sumber yang telah ada.

Adapun dalam penelitian ini yang termasuk data sekunder yaitu dokumen- dokumen yang terkait dengan penelitian. Wawancara dengan menentukan informan penelitian merupakan orang yang memiliki informasi tema atau hal yang diteliti. Adapun informan dalam penelitian ini yaitu: (1) Kapolres Madiun, I Made Prasatya; (2) Kasat Reskrim Polres Madiun, Hanif Fatih; (3) Penyidik Polres Madiun, Dwi Heroe; (4) Penyidik Pembantu Polres Madiun, Rohmawan; (5) Nanang Sucipto, Anggota PSHW; (6) Setyo Budi Utomo, Anggota PSHT; (7) Dino, Masyarakat Kecamatan Dipolo.

Dalam penelitian ini observasi juga dilakukan untuk dapat memahami proses terjadinya wawancara dan hasil wawancara dapat dipahami dalam konteksnya. Analisis data kualitatif dilakukan apabila data empiris yang diperoleh adalah data kualitatif berupa kumpulan berwujud kata-kata dan bukan rangkaian angka serta tidak dapat disusun dalam kategori- kategori/struktur klasifikasi. Analisis data dimulai dengan menelaah seluruh data yang tersedia dari berbagai sumber kemudian melakukan reduksi data dengan membuat ringkasan, mengkode, menyesuaikan temuan di lapangan dengan konsep teori yang digunakan. Kemudian dilakukan pemeriksaan keabsahan data dan penafsiran data untuk kemudian menarik kesimpulan dan verifikasi.

\section{Hasil dan Pembahasan}

\section{Strategi Polres Madiun dalam manajemen konflik pencak silat PSHT dan PSHW di Kabupaten Madiun}

Pada dasarnya, tindakan kepolisian terbagi menjadi tiga (3) yaitu pre-emtif, preventif, dan represif (Sendewana 2013; Astari 2016). Tindakan pre-emtif adalah pencegahan secara dini melalui optimalisasi kegiatan-kegiatan dibidang edukatif seperti pendidikan masyarakat dan pemberdayaan masyarakat. Kemudian, tindakan preventif merupakan tindakan yang dilakukan oleh pihak berwajib sebelum penyimpangan sosial terjadi dengan tujuan agar suatu tindakan pelanggaran dapat diredam atau dicegah. Sedangkan tindakan represif adalah tugas pokok kepolisian dalam aspek penegakan hukum, yang merupakan langkah terakhir setelah pre-emtif dan preventif seperti operasi rutin dan operasi gabungan. Dalam kaitannya dengan manajeman konflik Pencak Silat PSHT dan PSHW di Kabupaten Madiun, tahapan strategi Polres Madiun dapat dijabarkan sebagai berikut: 


\section{Tahapan preemtif}

Tindakan preemtif adalah tindakan yang dilakukan jauh hari sebelum terjadinya konflik terjadi, sehingga lebih tepatnya disebut kegiatan ini merupakan kegiatan pembinaan masyarakat. Meskipun telah banyak kasus konflik yang berupa penganiayaan, pengancaman yang muncul, namun ini tetap harus dilakukan untuk mencegah kasus demikian menjadi semakin meluas dan tidak terkendali. Sehingga perlu bimbingan melalui tokoh-tokoh organisasi atau masyarakat dari kedua organisasi tersebut.

\footnotetext{
"Tindakan pencegahan adalah hal yang paling secara kontinyu kami lakukan, seperti binluh/ Pembinaan dan penyuluhan, dengan bekerjasama dengan masyarakat lokal melalui toko-tokoh masyarakat dan perangkat lokal tentunya.” (IMP, Kapolres Madiun)

\begin{abstract}
"Ada, kegiatan bimbingan, pembinaan dan penyuluhan mengenai menjaga keamanan dan ketertiban bersama, bahkan kami meninggalkan beberapa banner yang terdapa slogan untuk bersama-sama menjaga daerah masih-masig dan beberapa nomor penting kepolisian yang bisa dihubungi jika ada laporan-laporan terkait kasus penganiyaan, pengeroyokan dan pengancaman." (HF, Kasat Reskrim Polres Madiun)
\end{abstract}

Fungsi preemtif sebagaimana yang dilakukan oleh Polres Madiun dengan kemudian meningkatkan kerja sama dengan Polsek-polsek di wilayah hukumnya, lebih bersifat kepada pemberian bimbingan, penyuluhan, dan pembinaan melalui pemasangan banner-Banner/ spanduk bertuliskan mengajak pada keamanan masyararakat serta mengarah kepada pembentukan masyarakat yang patuh dan taat hukum, serta mampu menolak setiap bentuk kejahatan Tindakan preemtif lebih mengarah pada penciptaan kondisi masyarakat yang memiliki daya tangkal tinggi terhadap semua jenis kejahatan (Azizah 2017; Sarkosi 2019). Pelaksanaan fungsi preemtif dilaksanakan oleh Bimmas atau bimbingan masyarakat yang sekarang sekarang diganti menjadi Binamitra. Tindakan preemtif ini sangat bermanfaat untuk meningkatkan keamanan, baik di wilayah perkotaan maupun di desa- desa di wilayah hukum Polres Madiun sebagai langka antisipasi munculnya faktor kondusif kejahatan. Dalam upaya menekan terjadinya kriminalitas, tidak terkecuali konflik seperti PSHT dan PSHW, dilakukan adanya giat opstin yang ditingkatkan yaitu menggunakan pola preventif (pencegahan) dengan cara bertindak tingkatkan Patroli, pengamanan dan pengawalan oleh Binmas dan Brimob dalam kegiatan masingmasing organisasi, termasuk Suran Agung yang merupakan sangat penting.

Polres Madiun melakukan tindakan preventif untuk mencegah terjadinya suatu tindak pidana di wilayah hukum Polres Madiun dengan menempatkan personil Kepolisian di daerah-daerah atau di tempat-tempat yang rawan terjadinya konflik, daerah yang rentan menjadi tempat-tempat konflik organisasi terus dipantau dan di awasi melalui giat patroli tersebut, dengan demikian maka Polres Madiun melakukan kegiatan antisipasi (tindakan preventif) melalui pengembangan patroli- patroli di daerah-daerah yang rawan kejahatan dengan membuat pos-pos penjagaan, membentuk patroli roda dua serta melakukan pengawalan- pengawalan terhadap pos-pos yang dekat dengan wolayah organisasi ini maka diharapkan dapat dilakukan pencegahan sedini mungkin terjadinya konflik kedua belah pihak. Secara teori, untuk memahami konsep dari pencegahan kejahatan, seyogianya tidak boleh terjebak pada makna kejahatannya, melainkan pada kata pencegahan (Gilling 1997; Schneider 2014; Purnomo 2019; Mustolish 2019). Hal yang perlu dicoba adalah dengan membongkar konsep dari pencegahan (prevention) itu dengan memecah katanya menjadi dua bagian unsur, yaitu prediksi (prediction) danintervensi (intervention). Perihal pengamanan, pengawalan serta patroli merupakan bentuk dari pencegahan dan intervensi tersebut.

\footnotetext{
"Perlu dilakukan intervensi, ini berarti kita tidak hanya diam mengawasi namun ada pengawalan sepanjang kegiatan Suran Agung tersebut.” (HF, Kasat Reskrim Polres Madiun)
}

Untuk mencegah terjadinya sesuatu hal (kejahatan) serta konflik PSHT dan PSHW pada kegiatan Suran Agung, yang pertama sekali harus dilakukan adalah memprediksi kemungkinan dari tempat dan waktu terjadinya, dan kemudian menerapkan intervensi yang tepat pada titik perkiraannya. Pencegahan kejahatan merupakan sebuah metode kontrol yang langsung, berbeda dari metode- 
metode pengurangan kejahatan yang lainnya, seperti pelatihan kerja, pendidikan remedial, pengawasan polisi, penangkapan polisi, proses pengadilan, penjara, masa percobaan dan pembebasan bersyarat, yang masuk ke dalam metode kontrol kejahatan secara tidak langsung (indirect control). Pencegahan kejahatan, secara operasional, juga dapat dijelaskan sebagai sebuah praktek manajemen risiko kejahatan. Manajemen risiko kejahatan melibatkan pengembangan pendekatan sistematis untuk pengurangan risiko kejahatan yang hemat biaya dan yang mempromosikan baik keamanan dan kesejahteraan sosial dan ekonomi bagi korban potensial (Sherman \& Eck 2003; Mareti 2010).

Pencegahan kejahatan berbasis masyarakat dapat meliputi Community policing, (Polisi Masyarakat) yaitu pendekatan kebijakan yang mempromosikan dan mendukung strategi untuk mengatasi masalah kejahatan melalui kemitraan polisi dengan masyarakat, yaitu sebuah strategi pengrehan masyarakat, di mana kelompok- kelompok dalam masyarakat mengatur, mencegah, dan melaporkan kejahatan yang terjadi dilingkungan mereka (Sloknick \& Bayley 1988; Ganapathy 2000). Selain itu dapat juga dilakukan dengan pemberlakuan program-program seperti Comprehensive Communities, yang menggabungkan beberapa pendekatan untuk menanggapi masalah dalam masyarakat; dan dengan aktivitas penegakan hukum khusus yang berhubungan dengan kejahatan.

\section{Tahapan represif}

Tahap ketiga, setelah preemtif dan preventif adalah penegakkan hukum (Gakkum) dimana menjalankan fungsi represif. Beberapa upaya represif Polres Madiun dalam menanggulangi konflik PSHT dan PSHW adalah yaitu: (1) Koordinasi dengan jajaran polsek di hukum wilayah administratif. Koordinasi dapat dilakukan dengan cara melakukan hubungan kerjasama yang erat dengan polsek di bawah Polres Madiun. Oleh karena itu, dengan kerjasama antar polsek dengan meningkatkan kewaspadaan di tiap-tiap wilayah akan membantu mengurangi tingkat kejahatan akibat konflik organisasi bela diri di wilayah hukum Polres Madiun; (2) Analisis data residivis, salah satu hal yang merusak sistem masyarakat adalah adanya penjahat kambuhan atau yang biasa disebut dengan residivis para penjahat ini biasanya mengulang kejahatan yang sama, meskipun dia sudah pernah dijatuhi hukuman. Sebagai contoh seseorang telah melakukan pengeroyokan dan kembali melakukan pengeroyokan dengan pengancaman senjata tajam.

"Pernah, yang pertama pada tahun 2014 ya ejek-ejekan di jalan, dan dia tidak terima akhirnya dia melapor sama anggotanya dan akhirnya saya dikeroyok, terus ya saya melapor juga sama anggota dan terjadi konflik, dan saya di keroyok lagi sama orang yang sama." (NN, Pelaku)

Terhadap seseorang melakukan tindak pidana, seperti contoh diatas dapat dianggap mengulangi kejahatan yang sama (residivis) dan dapat dijadikan dasar pemberat hukuman nya berdasar kan ketentuan Pasal 486 KUHP ia dapat diancam hukuman sepertiga lebih berat dari ancaman hukuman yang normal dengan catatan bahwa perbuatan yang jenis nya sama tersebut ia lakukan dalam kurang dari waktu 5 tahun setelah menjalani hukuman yang dijatuhkan. Resivis terjadi dalam hal seseorang yang melakukan tindak pidana dan telah dijatuhi pidana dengan suatu putusan hakim yang telah berkekuatan hukum tetap (inkracht van gewijsde), kemudian melakukan tindak pidana lagi sama seperti dalam concursus relais, dalam recidive terjadi beberapa tindak pidana namun dalam resividis tidak ada putusan hakim yang telah berkekuatan hukum tetap. Peraturan substansial yang ada dalam Undang-Undang Pemasyarakatan ini di jadikan landasan berpijak bagi warga binaan pemasyarakat dan pembina secara terintegrasi pada satu sitem pemasyarakatan di Indonesia, maka undang-undang pemasyaraktan adalah sebagai kerangka berpijak perilaku yang pantas dan standar untuk bertindak.

Pada umumnya, tindakan represif lebih mengarah pada penerapan hukum yang ada untuk diterapkan pada kejahatan-kejahatan yang sudah terjadi. Tindakan ini melibatkan sistem peradilan pidana dimulai dari proses penyelidikan, penyidikan, penuntutan, hingga pemeriksaan di pengadilan dan penyerahan terpidana ke Lapas. Hal ini juga dilakukan oleh Polres Madiun berperan dalam hal ini melaksanakan proses penyelidikan dan penyidikan (lidik dan sidik) terhadap kasus pengeroyokkan, pengancaman dengan senjata tajam, dan perusakan barang atau benda milik orang lain. 


\begin{abstract}
"Upaya paling akhir kami adalah menyidik kelompok- kelompok yang sebenarnya telah pernah dihukum dan mengulangi kejahatannya lagi. Karena kita ketahui organisasi ini memang memiliki sejarah yang berbeda, kepentingannya juga berbeda, sehingga konfliknya turun menurun pada anggota. Hal ini yang kini terus menjadi target pemberantasn utama." (HF, Kasat Reskrim Polres Madiun)
\end{abstract}

Secara prosedural, Polres Madiun akan langsung melakukan tindakan represif berupa tindakan upaya paksa dengan menerapkan hukum pidana (penerapan penal) jika telah terjadi tindak pidana sebagaimana dimaksud dalam kasus tindak pidana pengancaman dengan senjata tajam. Selanjutnya Polres Madiun akan menerima laporan, langsung melakukan olah TKP dan melakukan penyelidikan. Selanjutnya berdasarkan informasi-informasi yang diterima dan hasil olah TKP tersebut dilakukan upaya paksa untuk menangkap para pelaku yang kemudian dilanjutkan ke proses penyidikan untuk dibuat berkas perkaranya. (Berkas perkara yang sudah lengkap dikirim ke JPU dan setelah dinyatakan lengkap (P-21) maka Polres Madiun menyerahkan tersangka beserta barang bukti dengan demikian maka proses selanjutnya Jaksa melakukan menuntutan dan para tersangka ditingkatkan statusnya menjadi terdakwa untuk disidangkan di sidang pengadilan.

\title{
Kendala-Kendala yang Dihadapi Polres Madiun dalam manajemen konflik pencak Silat PSHT dan PSHW di Kabupaten Madiun
}

Faktanya, ada beberapa hal yang masih menjadi kendala untuk menanggulangi konflik PSHT dan PSHW di Kabupaten Madiun, adapun kendala tersebut yaitu:

\section{Kendala internal}

Kendala internal yang dialami yakni: (1) Biaya Operasional yang tersedia kurang memadai, karena biaya yang di keluarkan untuk proses penyidikan cukup besar. Sekali dalam melakukan proses dari tahapan preemtif, preventif hingga reprsif biaya yang dibutuhkan adalah sebesar RP. $5.000 .000 \mathrm{~s} / \mathrm{d}$ 10.000.000, sedangkan anggaran dasar yang diterima oleh penyidik Unit Reserse di setiap Polsek di wilayah hukum Polrestabes dalam melakukan proses penyidikan yakni sebesar Rp. 3.000.000. s/d Rp. 5.000.000; (2) Lemahnya koordinasi dan kerjasama antara Kepolisian dengan pihak-pihak dan instansi- instansi terkait yang berakaitan dengan penanganan konflik PSHT dan PSHW tersebut. Terlihat dengan jelas hubungan antara anggota satuan fungsi lainya dan Reskrim kurang maksimal, belum nampak kegiatan berjalan secara efektif dalam penanganan Tindak Pidana, hubungan Satuan Reskrim dengan masyarakat terutama terkait dengan perkara pidana masih belum maksimal, hal ini dapat dilihat dari keluhan-keluhan masyarakat terhadap pelayanan Penyidikan kasus pengancaman, penganiayaan dan pengeroyokan pada anggota kedua perguruan Setia Hati tersebut; (3) Quick Respon, lambatnya pihak kepolisan ditingkat Polsek mendatangi TKP, kurang cekatan dalam merespon laporan dari masyarakat terkait dengan kasus pengancaman, penganiayaan dan pengeroyokan pada anggota kedua perguruan Setia Hati.

\section{Kendala eksternal}

Kendala eksternal yang dialami yakni: (1) Kuranganya kesadaran dari masyarakat apabila melihat terjadi pengancaman, penganiayaan dan pengeroyokan pada anggota kedua perguruan Setia Hati yang dilihat lansung di TKP, masyarakat tidak lansung melapor kepada pihak Kepolisan setempat, sehingga secara otomatis menghambat penanganan kekerasan atau konflik antara kedua organisasi tersebut. Hal ini karena masyarakat enggan terlibat oleh masalah organisasi PSHT maupun PSHW; (2) Kurangnya saksi yang dimintai keterangan dalam kasus pengancaman, penganiayaan dan pengeroyokan pada anggota kedua perguruan Setia Hati, dalam hal ini pasti kepolisan kesulitan dalam mengumpulkan bukti dan fakta fakta yang terjadi dilapangan; (3) Setiap tahun jumlah anggota dari kalangan anak remaja meningkat. Padahal remaja masih sangat labil, sehingga mudah terpancing emosi. Perlu pembinaan yang kuat oleh Polres Madiun, karena masih labil tersebut. 


\section{Simpulan}

Tahapan strategi Polres Madiun dalam manajemen konflik Pencak Silat PSHT dan PSHW di Kabupaten Madiun yaitu tahapan preemtif dengan cara pembinaan dan penyuluhan dengan tokoh masyarakat dalam organisasi PSHT dan PSHW. Tahapan preventif dilakukan dengan pelaksanana patroli (operasi rutin), pengawasan serta operasi gabungan. Tahapan represif terkait fungsi penegakkan hukum melalui pelaksanaan UU No. 2 Tahun 2002 Pasal 2, yaitu dengan cara koordinasi dengan jajaran polsek di hukum wilayah administratif dan analisis data residivis.

Kendala internal dalam manajemen konflik Pencak Silat PSHT dan PSHW di Kabupaten Madiun antara lain Biaya Operasional yang tersedia kurang memadai, Lemahnya koordinasi dan kerjasama antara Kepolisian dengan pihak-pihak dan instansi-instansi terkait. serta lambatnya pihak kepolisan ditingkat Polsek mendatangi TKP, kurang cekatan dalam merespon laporan dari masyarakat terkait dengan kasus pengancaman, penganiayaan dan pengeroyokan pada anggota kedua perguruan Setia Hati. Sedangkan kendala eksternal antara lain kuranganya kesadaran dari masyarakat apabila melihat terjadi pengancaman, penganiayaan dan pengeroyokan pada anggota kedua perguruan, serta kurangnya saksi yang dimintai keterangan dalam kasus pengancaman, penganiayaan dan pengeroyokan pada anggota kedua perguruan Setia Hati, dalam hal ini pasti kepolisan kesulitan dalam mengumpulkan bukti dan fakta fakta yang terjadi dilapangan.

\section{Daftar Pustaka}

Astari P (2016) Landasan filosofis tindakan diskresi kepolisian terhadap anak yang berhadapan dengan hukum. Arena Hukum 8 (1):1-18.

Azizah UN (2017) police barriers in technical and technical violation distribution by drivers bike motorcycle. E-CIVICS 6 (2).

Colas D (1997) Civil Society and Fanaticism: Conjoined histories. Stanford University Press.

Coser LA (1998) The Functions of Social Conflict (Vol. 9). Routledge.

Coser LA (1967) Continuities in the Study of Social Conflict. Free Press.

Dahrendorf R (2011) The Modern Social Conflict: The politics of liberty. Transaction Publishers.

Dahrendorf R (1958) Toward a theory of social conflict. Journal of Conflict Resolution 2 (2):170-183.

Ganapathy N (2000) Conceptualising community policing, crime prevention and criminology: A Singapore perspective. Australian \& New Zealand Journal of Criminology 33 (3):266-286.

Gilling D (1997) Crime Prevention: Theory, Policy and Politics. Psychology Press.

Indriatmiko P (2016) Pengembangan "Kampung Pendekar Madiun" sebagai Pusdiklat Atlet Pencak Silat dan Wisata Raga (Doctoral dissertation, Universitas Muhaammadiyah Surakarta).

Iswati R, Wiyaka A \& Utami SB (2018) Membangun Pranata sosial dalam mereduksi konflik di Perguruan Silat Setia Hati Terate (PSHT) dan Perguruan Silat Setia Hati Tunas Muda Winongo (PSHW) di Madiun. In Seminar Nasional Sistem Informasi (Senasif) 2 (1):1584-1592).

Kartomi M (2011) Traditional and modern forms of pencak silat in Indonesia: The Suku Mamak in Riau. Musicology Australia 33 (1):47-68.

Kumaidah E (2012) Penguatan eksistensi bangsa melalui seni bela diri tradisional pencak silat. HUMANIKA $16(9)$.

Mardotillah M \& Zein DM (2017) Silat: Identitas budaya, pendidikan, seni bela diri, pemeliharaan kesehatan. Jurnal Antropologi: Isu-Isu Sosial Budaya 18 (2):121-133.

Mareti B (2010) Implementasi manajemen risiko kejahatan perampokan pada pengiriman uang tunai (Studi kasus pengiriman hasil pendapatan PT ABC Cabang X). Indonesian Journal of Criminology:4195.

Maksum A (2009) Konflik kekerasan antar kelompok perguruan pencak silat: Proses pembentukan identitas sosial yang terdistorsi. Dalam “Anima”, Indonesian Psychological Journal 24 (2).

Laqueur W (2000) The New Terrorism: Fanaticism and the arms of mass destruction. Oxford University Press on Demand. 
Mohamad M (2018) Pengaruh regulasi diri terhadap agresivitas anggota Perguruan Silat Beladiri Tangan Kosong Merpati Putih dan Persaudaraan Setia Hati Terate di Madiun (Doctoral dissertation, Universitas Islam Negeri Maulana Malik Ibrahim).

Mustolih I (2019) Program Polisi Mitra Rukun Warga dalam Mewujudkan Keamanan dan Ketertiban Masyarakat di Polres Kota Malang. Jurnal Sosiologi Dialektika 14 (1):52-58.

Purnomo HD (2019) Peran Tim Anti Bandit Satreskrim Polrestabes Surabaya dalam penanggulangan tindak pidana kejahatan jalanan. Jurnal Sosiologi Dialektika 14 (1):34-43.

Olson J (2007) The freshness of fanaticism: The abolitionist defense of zealotry. Perspectives on politics 5 (4):685-701.

Prastya A (2016) Konflik Kekerasan Antara Pendekar Silat Dalam Perspektif Sosiologi (Studi Konflik antar Pendekar Silat di wilayah Madiun). In: Indonesia Yang Berkeadilan Sosial Tanpa Diskriminasi, 19 Oktober 2016, UTCC.

Rosanty D (2011) Sejarah dan Dinamika Konflik antara Perguruan Pencak Silat Setia Hati Terate dan Setia Hati Winongo di Kabupaten Madiun (Doctoral dissertation, Universitas Gadjah Mada).

Sarkosi E (2019) Aplikasi Go Sigap sebagai wujud peningkatan pelayanan publik yang lebih mudah bagi masyarakat dengan berbasis teknologi informasi. Jurnal Sosiologi Dialektika 14 (2):84-94.

Schneider S (2014) Crime Prevention: Theory and Practice. CRC Press.

Sendewana B (2013) Studi kasus mengenai tembak di tempat tersangka oleh kepolisian. LEX ET SOCIETATIS 1 (3).

Sherman LW \& Eck JE (2003) Policing for crime prevention. In Evidence-based crime prevention:309-343). Routledge.

Toscano A (2017) Fanaticism: On the Uses of an Idea. Verso Books.

Undang-Undang Republik Indonesia Nomor 2 Tahun 2002 Tentang Kepolisian Negara Republik Indonesia.

Wilson ID (2002) The Politics of Inner Power: The Practice of Pencak Silat in West Java (Doctoral Dissertation, Murdoch University). 